\title{
MAKING THE LEAN START-UP METHOD WORK: THE ROLE OF PRIOR MARKET KNOWLEDGE
}

\begin{abstract}
A large majority of growth-oriented ventures extensively uses venture experimentation popularized by the lean start-up method, yet we know very little about the boundary conditions under which this method can be successful. Using a longitudinal multiple case study method, we investigate how growth-oriented ventures apply the lean start-up method to achieve early venture success. We find that the presence of prior market knowledge is an important boundary condition for successfully applying the lean start-up method. We also contribute to the absorptive capacity literature by clarifying how new ventures build absorptive capacity early in their venture lifetime.
\end{abstract}

Keywords: Venture experimentation, market knowledge, growth-oriented ventures, lean start-up

\section{INTRODUCTION}

Setting up a new technology venture is risky as environments become more complex and uncertain, changing at faster rates than ever before. In addition, early resource and business model choices in these environments could have path depending effects and impact future venture growth (Bhawe, Rawhouser, and Pollack 2016). Under these conditions, theories and methods have emerged to support entrepreneurs to deal with such environments (Camuffo, Cordova, and Gambardella 2017). One very popular method advocated by entrepreneurs, mentors and investors and taught in entrepreneurship courses around the world is the lean startup method (LSM). Entrepreneurs using this method enter markets with minimal viable products (MVPs), fail quickly and cheaply, and adapt the offering and supporting business model as they penetrate the market (Ries 2011; Blank 2013; Vogel 2016).

The LSM shares principles with recent but also more established theories in entrepreneurship and management such as lean manufacturing (Krafcik 1988), agile development (Highsmith and Cockburn 2001), design thinking (Archer 1965; Martin 2009; Smith and Eppinger 1997) and discovery-driven planning (McGrath and McMillan 1995; 2009). 
These theories emphasize the importance of experimentation as a key tool for innovators and entrepreneurs to deal with the uncertainty and complexity that today's technological (r)evolutions bring about. Eventually, adopting the lean start-up principles should result in early successes (e.g. raising external capital), supporting the growth of the venture. Unfortunately, we still lack a thorough understanding of the boundary conditions under which this method can be applied successfully.

To address our research question, we used a longitudinal, multiple case study design (Eisenhardt 1989; Eisenhardt and Graebner 2007) and followed four London-based, growthoriented ventures in the first two years of their existence. Our results show that two ventures were successful in adopting the LSM resulting in raising a significant amount of external finance. Obtaining venture capital can be seen as a proxy for the validation of the value proposition or achieving product-market fit (Root n.d.) as venture capitalists scrutinize their investment opportunities for product-market fit. Furthermore, acquisition of venture capital funding constitutes one of the most important milestones for technology ventures, is a credential of quality and improves their likelihood of success (Fitza, Matusik and Mosakowski 2009; Hellmann and Puri 2002; Hochberg, Ljungqvist and Lu 2007; Hsu 2007). The other two ventures failed to apply successfully the LSM and eventually stopped their business or transformed it into a lifestyle business with no specific growth ambitions.

While all four ventures used the LSM, we find that the two ventures that were unsuccessful in securing venture capital were not adequately applying its principles as they lack prior market knowledge. In this study, we argue that only when the LSM is combined with the capacity to interpret and subsequently act upon acquired market information, entrepreneurs are able to learn from market information. The LSM is thus constrained by the presence of prior 
market knowledge. Ventures that lack prior market knowledge engage in an unplanned and unguided process of trial-and-error learning where the outcomes of their experiments do no lead to convergence, thereby burning their limited resource base before validation of their business model is achieved.

Our study makes several contributions to the entrepreneurship and strategy literature. First, we contribute to the venture experimentation literature by explaining that the level of prior market knowledge is an important boundary condition for successfully applying the LSM. When entrepreneurs have no prior market knowledge, they are less able to interpret the market information collected through experimentation with users/customers. This finding resonates with the organizational learning literature and market-based organizational learning in particular (Sinkula 1994). While the interpretation of market information is key to organizational learning, there is surprisingly little attention in entrepreneurship research on how entrepreneurs interpret and process market information. Moreover, by embedding the application of LSM in the literature on venture experimentation, we also provide a stronger theoretical foundation for this method. Second, we contribute to the absorptive capacity and organisational learning literatures (Cohen and Levinthal 1990; Zahra and George 2002) by showing how new ventures can create the absorptive capacity to learn from market feedback. We find that the ability to interpret acquired knowledge and information of a new venture can either be internal (via prior market knowledge of team members) or external (via social resources) to the venture. In addition, we suggest that there may be a dynamic aspect to absorptive capacity development. Entrepreneurs may accelerate the development of internal absorptive capacity through close and frequent interactions with external sources of absorptive capacity. 


\section{THEORETICAL BACKGROUND}

\section{LSM: origin, definition and development}

Since its launch in 2008, the LSM as introduced by Eric Ries has been experiencing an everincreasing popularity among entrepreneurs and entrepreneurship academics alike. While originally the method was mainly used by high-tech start-ups, its current application goes far beyond Silicon Valley start-ups (Gbadegeshin and Heinonen 2016; Harms 2015; Nirwan and Dhewanto 2015), and even includes big corporations, incubators and accelerators (e.g. Cohen and Hochberg 2014) and universities worldwide (e.g. Lutz et al. 2017). Applying ideas from lean thinking to the process of innovation (Ries 2011), the LSM is a process where entrepreneurs translate their vision into falsifiable business model hypotheses, then test these hypotheses using a series of MVPs. Based on test feedback, entrepreneurs then decide whether to persevere, pivot or abandon the business model (Eisenmann, Ries, and Dillard 2012).

Eric Ries introduced the "lean start-up" concept on his blog in $2008^{1}$. However, the roots of the LSM can be found with Steve Blank (2007) who was the first to stress the importance of testing and refining business hypotheses through customer validation, a process referred to as customer development. Later, the LSM was complemented with the business model canvas (Osterwalder and Pigneur 2013), providing a tool for continuous improvement and allowing its users to summarize, test and refine entrepreneurial hypotheses (Tanev et al. 2015). This led to a modified version of the business model canvas, the lean canvas developed by Maurya (2012a), which emphasizes the process of searching for a scalable business model by testing the most critical and risky assumptions first, i.e. problem understanding and solution (Maurya 2012b).

\footnotetext{
${ }^{1}$ Rasmussen and Tanev provide a helpful overview of the history of the lean startup movement and underlying principles (Rasmussen and Tanev 2016)
} 


\section{LSM: theoretical foundations and literature}

While the LSM is a practitioner-driven methodology, the intellectual roots of this method can be traced back to some streams in the management literature, including the literature on product development in particular discovery driven planning, design thinking and customer development, lean manufacturing and agile development (Ries 2011). However, the theoretical underpinning of the method often remains implicit, rendering it more difficult to further develop and investigate it. In table 1, we present an overview of these underlying theoretical frameworks and relevant principles. Further, we add the literatures on venture experimentation, effectuation and bricolage to the table to represent the academic research streams on this topic.

\section{---INSERT TABLE 1 HERE---}

In essence, the LSM does not introduce radically new principles but instead integrates principles from existing management theories with the objective to allow entrepreneurs to deal with the uncertainty inherent to starting a new venture. The LSM borrows from the theory of discovery driven planning (McGrath and McMillan 1995; 2009) the principle of experimentation and assumption testing and from the literature on design thinking the importance of experimentation in interaction with users/customers (Thomke 1998; 2001). Whereas the latter mainly focus on interacting with users and customers early on to increase product design success, the LSM involves a broader set of stakeholders to validate not only the design of the product/solution but the entire business model developed around it. By combining these principles with the idea of waste minimization as introduced by Krafcik (1988) on lean manufacturing, the LSM reduces risk and uncertainty by ensuring the start-up does not commitment more resources without a proper indication of market acceptance. Using MVPs to test assumptions reflects this idea. Finally, the idea to pivot based on the feedback gathered from 
customers originates from the agile development movement (Highsmith and Cockburn 2001) which in turn resembles flexible planning as introduced by Iansiti and colleagues (Iansiti and MacCormack 1997; MacCormack, Verganti, and Iansiti 2001).

Next to these theories and frameworks, LSM could also benefit from a better integration with research on venture experimentation. The literature on venture experimentation revolves around "the processes of deliberate and purposeful developing and testing hypotheses about a business model, in a controlled or real-life environment" (Bojovic, Genet, and Sabatier 2018). The LSM in turn builds on the idea that entrepreneurs need to learn from the market quickly via experimentation to develop their business model and therefore clearly fits within a broader literature on venture experimentation (Nicholls-Nixon, Cooper, and Woo 2000; Thomke and Manzi 2014; Gans, Stern, and Wu 2016). However, the practitioner-oriented literature on LSM and the academic literature on venture experimentation tend to exist next to each other as there is little referral between these two literatures. Literature on venture experimentation argues that entrepreneurship is fundamentally about experimentation because the knowledge required to be successful cannot be known in advance (Kerr, Nanda, and Rhodes-Kropf 2014). Entrepreneurs often work in highly uncertain environments where they lack sufficient data to inform their decisions (Thomke and Manzi 2014). Venture experimentation, via engaging customers in conversations or building products and/or service prototypes, allows entrepreneurs to collect signals (additional information) about the value of entrepreneurial ideas, manage risk levels, and improving business outcomes (Camuffo et al. 2017). In addition, it can also give entrepreneurs the confidence to overturn wrongheaded conventional wisdom and the faulty business intuition that even seasoned entrepreneurs can display (Thomke and Manzi 2014). 
Besides the literature on venture experimentation, the LSM also shows similarities with effectuation (Sarasvathy 2001) and entrepreneurial bricolage (Baker and Nelson 2005). These constitute two widely cited emerging theories in entrepreneurship research offering a general explanation of entrepreneurship (Fisher 2012). Both effectuation theory and entrepreneurial bricolage acknowledge the importance of means at hand to shape entrepreneurial outcomes and follow an approach of social or environmental interaction towards opportunity development. Where effectuation theory argues that opportunities are shaped by engaging in stakeholder interaction and co-creation (Sarasvathy 2001), bricolage focalizes around the idea that the resource environment is constructed by entrepreneurs as they find new uses for existing resources and/or reject the prevailing definitions of resources (Baker and Nelson 2005). Similar to LSM, these theories share the importance of interacting with the environment and by doing so, entrepreneurs shape and co-create opportunities. However, the intentionality of these interactions differ across the three frameworks. Where according to bricolage the purpose of the interactions revolves around resource development, in LSM interactions serve to validate the value proposition and business model. According to effectuation finally, stakeholder interaction serves to gather means and narrow down goals.

The popularity of the LSM led to a number of articles that further refine the methodology and offer specific guidelines on how to implement the various steps (Breuer 2013; Gbadegeshin and Heinonen 2016), while others have questioned the applicability of the LSM in different contexts (Harms, Marinakis, and Walsh 2015; Still 2017). Further, despite a strong belief among many entrepreneurs that the LSM will drive venture success, we know very little about the performance implications of this method. Camuffo et al. (2017) offer a notable exception and 
find that this scientific hypothesis driven approach of testing your business ideas with early customers leads to better venture results (measured as revenues and drop outs).

At the same time, criticism on the effectiveness and general applicability of the LSM is growing. Gans et al. (2016) criticise the commitment-free learning that this method would imply arguing that after a test is conducted, it is possible to then subsequently make a choice independent of the impact that the experiment itself has had on the evolution of the venture. Other authors predict that the method will decrease the bandwidth of broader search (Ladd and Kendall 2017) or that experiments may only lead to small wins as the cost of running them may be greater than the measured benefits (Kohavi et al. 2013). Furthermore, the number of experiments required may be so large that only a handful of firms can leverage experiments successfully (Lewis and Rao 2015). The objective of the current paper is therefore to add to this debate by investigating under what conditions the application of the LSM leads to performance benefits.

\section{METHOD}

As the venture experimentation literature does not provide many insights on how entrepreneurs can successfully apply venture experimentation methods such as the LSM and learn from each experiment to quickly narrow down the search for a product-market fit, we used a qualitative multiple case study approach to investigate this particular phenomenon (Eisenhardt 1989; Eisenhardt and Graebner 2007). We opted for this approach because theory-building research using cases is particularly strong in answering research questions that address "how" and "why" in unexplored research areas (Pratt 2009; Eisenhardt and Graebner 2007). Our goal is not to create a fundamentally new theory, but rather to use the multi-case approach to elaborate existing 
theory on venture experimentation (Gehman et al., 2018; Ahsan et al. 2018). Hence we do not use a purely grounded approach, where insights are generated only through data starting from a blank slate (Danneels 2003). Instead, we draw on extant theory, concepts and models as a starting point for a study to elaborate theory (Danneels 2003; Vaughan 1992). We compare and contrast existing theories with the phenomenon of the LSM, clarify the conditions under which it becomes effective, and most importantly, generate new theory to guide understanding of the phenomenon (Shepherd and Sutcliffe 2011; Ahsan et al. 2018). Following the multi-case study approach, we collected data from different sources over time. As part of our longitudinal design, we interviewed the founders at several points in time and collected different secondary data following the evolution of their venture. This makes it possible to track the process of the LSM (build-measure-learn feedback loop) over time and to analyse how ventures' resource configurations evolve after going through different iterations (see data collection part). Finally, the within and cross case analyses as part of the multi-case study approach (see data analysis part; Eisenhardt, 1989) enables researchers to observe contrasting patterns more easily across different cases. Through our cross case analyses, we build a better understanding of why some ventures successfully apply venture experimentation methods while others struggle and need to compromise on their growth ambitions.

\section{Data collection}

We identified an initial pool of start-ups on a networking event called "Silicon Valley comes to [name business school]" that was organised by a start-up accelerator at a London-based business school in 2012. Since accelerators typically attract growth-oriented ventures (Bosma and Stam 2012), this event was an interesting setting to identify appropriate cases for our study. Four ventures accepted to participate in our study. Founded by young and recent graduates in 2011- 
2012, they are set-up in the London start-up scene and are active in the ICT sector. We selected cases from one sector in one particular city because this reduces potential biases of environmental heterogeneity. All four ventures (MEC, GRO, LOC, and HEL) started with very limited resources $(<£ 5 \mathrm{k}$ start-up capital) and followed the LSM from founding onwards. At the same time, all four ventures indicated that they had growth ambition. As one of the founders of LOC stated in the first year of their existence:

"We all put some money in when we started LOC, and the intention is that we would eventually get to a stage where we could get some kind of seed funding or angel investment to accelerate our growth." (LOC, 2012).

The founder of GRO described his ambition as follows:

"Steve Jobs, Elon Musk, Mark Zuckerberg, I want to be in the same cracking of those people. A tech entrepreneur, having a public company floating on Nasdaq... something similar to Google, that's it!"

The data collection is a combination of conducting different founder interviews over time while keeping track of their ventures by following the updates on the company website, social media channels and press coverage during a period of two years. We conducted four formal interviews with each company and had frequent follow-up e-mail and phone conversations. We interviewed the founders face-to-face just after they had set-up their venture and interviewed them again two years later. Shortly after the first (2012-2013) and second interview rounds (2014) we developed a list of the resources supporting the business model for each of the four cases and interviewed them again to check the list of resources.

In order to be able to conduct a comparative analysis between the cases, we developed an interview protocol to guide the semi-structured interviews. During the interview, we asked openended, probing and rephrasing questions to capture experiences and clarify details. The interview structure consisted of three sections. First, we collected information about the founders' 
backgrounds, growth ambitions, their founding story and reasons for following a LSM. The second section contained questions asking for the business and revenue model, the venture markets, product and services. Finally, we asked questions about the resource portfolio to support the business model. Whereas the interviews in the first round were broader in scope, the interviews in second round focused more on the specific aspects that were relevant to our study. In the second interview round, we also showed the list of resources from the first interview round and asked the respondents to indicate the changes in their resources and business model. We recorded and transcribed each interview. The duration of the interviews ranged from 45 to 90 minutes. Most interviews were conducted by two interviewers to ensure investigator triangulation by allowing interviewers to compare impressions and avoid blind spots (Ma and Seidl 2016; Patton 2002). The transcribed interviews amounted to 168 pages of single-spaced text. We also kept personal notes made before, during, and after the interviews, which included informal observations and discussions not recorded as part of the formal interviews.

To complement our primary data, we also collected secondary public data for triangulation. By collecting company documents, we were able to closely follow the start-ups during the two-year period. We collected and analysed press releases, articles in public press, blog posts and various information on the company's corporate website. Additionally, we also collected different versions of LinkedIn profiles of the founders and employees over time. The secondary data amounted to an additional 147 pages of single-spaced text. This data collection was also important as a input for the follow-up interviews and e-mail conversations. Table 2 summarizes the different data sources used to develop our findings.

\section{Data analyses}


We follow a partially grounded approach starting from existing concepts of the venture experimentation and entrepreneurship literature to elaborate existing theory on venture experimentation by analysing the data and clarifying the relationships between these concepts (Gehman et al. 2018; Ahsan et al. 2018). We looked for general patterns using the within and cross analyses inherent to the multiple case study approach (Eisenhardt 1989; Ahsan et al. 2018). We start by gaining a deep understanding of each single case (step 1), then comparing multiple cases of ventures to identify differences and similarities (step 2) in order to generate insights that improve our understanding of how ventures effectively apply popular venture experimentation methods such as in our study the LSM (step 3) (Ahsan et al. 2018). In the final step, we compare our emergent insights with that of the existing venture experimentation literature and discuss our similarities and new advances (step 4). In what follows, we explain these steps in more detail.

In the first step, we compiled individual case histories by synthesising information from multiple sources. We conducted a critical event analysis (Ariño and Ring 2010; Miles and Huberman 1984) and chronologically mapped the most important events of each case on different venture timelines that were included in the case descriptions. We used the interviews and company documents to construct and further cross check our timeline. We also developed a list of resources supporting the start-up's business model building on the resource orchestration framework put forward by Sirmon and colleagues (2011). During the interviews, we developed in detail their current resource configuration and discussed changes they made. These withincase analyses provided us with a better understanding of how these ventures managed their resources over time to support their business model and its iterations.

Second, we performed cross-case analyses and observed that two cases (MEC and LOC) succeeded in acquiring money to finance their growth ambitions while the other two cases were 
not successful in realizing their growth ambitions (one case stopped its activities (GRO) and one case turned into a lifestyle business (HEL)). The venture experimentation literature provided conceptual frameworks to support the interpretation of the data. The analysis of the data directed us to new concepts and theories in the literature to understand why ventures are successful in adopting the LSM. For example, we identified that for new ventures using the LSM, market interpretation using prior market knowledge appeared to be crucial (see findings) which directed us to the literature on absorptive capacity and organizational learning (Cohen and Levinthal 1990; Zahra and George 2002, Sinkula 1994).

We derived these new insights by highlighting and coding critical passages in the interviews and company documents. While reading and analysing the data, we made interpretative notes and compared our observations with the academic literature. Based on these interpretative notes and the academic literature, we generated memos. This iterative process of constantly comparing emergent theory and data led to additional, often more qualified and refined memos. Memos are brief analytic notes that include the insights of the researcher as he/she analyses the data and the emerging theory (Danneels 2007; 2011). The memos of all authors were discussed during several meetings and organised in different categories that eventually formed the building blocks of the findings sections. This step helped us to also further define the ability to interpret acquired market information as either internally (via prior market knowledge of team members) or externally (via social resources) to the venture. The collection of memo's based on our interviews over time in combination with the mapping of resources (step 1) also allowed us to better understand the dynamic interplay between internal and external absorptive capacity. 
Finally, we tested the validity of our findings by crosschecking and discussing the study's results with the main actors during different follow-up emails and phone interviews. This helped us to structure and contextualize findings and test whether our interpretations of the venture were consistent with those of the founders (Sonenshein 2014). Second, we further contrasted our findings with the current literature on venture experimentation to summarize in which way our findings are similar or contradict to existing theory.

---INSERT TABLE 3 HERE---

\section{Case descriptions}

Table 3 provides an overview of the main characteristics of the ventures. MEC was founded in 2012 with the aim to develop an online platform where people that have to repair their car can enter to get instant, industry standard approved quotes and book a mechanic online The lead founder comes from a family with extensive experience in the car industry. He followed a Master in Entrepreneurship at a leading business school in the UK where he did his thesis on the car repair industry and wrote the first draft of a business plan of MEC. Subsequently, he entered a London-based tech accelerator where he met his co-founder and started MEC. While the lead founder has previous start-up experience, the co-founder has experience in the development of apps.

GRO is a company founded in 2011 and provides customers with a credit card that they can use to sign in on different offers on GRO' online platform. In this way, groups of customers are able to sign in on deals and get discounts or extra options, saving money in a discrete fashion. According to one of the founders, GRO offers "the good deals of Groupon with the class of a dining card, and adds the social aspect of making it a group activity". While the lead founder graduated as an engineer and has mainly work experiences in management consulting, his co- 
founder studied finance and accounting and worked as a music artist manager. Together they had the necessary skills for front-end development of the website but neither of the founders had experience in the deals or dining cards markets.

LOC is founded in 2012 by three entrepreneurs: a technical consultant, a commercial strategy specialist, and a software engineer. LOC is built around a location search technology that leverages open data sets on transportation time, local amenities, to advice users searching for a new house/apartment where they would like to live. The founding team has strong technical skills but does not have any real estate experience.

HEL is a software start-up founded in 2011 by two entrepreneurs who studied computer science at a top university. While in university, they started HEL to make consumer apps for mobile devices. Their first and main product was a simple task manager app with a clutter-free interface, which makes it easier to stay organised. While the founders had strong programming skills, the did not have any market experience.

\section{FINDINGS}

\section{Gathering market information via iterative process}

We found that all four cases engaged extensively in experimenting with their solution to get feedback early on from users and other partners that play a role in the envisioned business model. This feedback would allow the entrepreneurs to increase the problem-solution fit and thus market success. For example, the founder of MEC told us the following in 2012:

"[...] we had multiple iterations, probably 10 to 20 already and there are probably gonna be many more in the near future [...]. We use these iterations to validate our concept. We speak to multiple users and multiple mechanics, we build a minimum viable product based on their input, put the product alive, seeing if people are using, paying for it and so on... just trialling different things. We are basically using the LSM." (MEC, 2012). 
The entrepreneurs used different techniques to gather feedback from users such as face-to-face interviews with users like in the case of MEC or via online blogs and forums as used by LOC and HEL. The founders of LOC and HEL explained us why such feedback is valuable:

"I just wrote a post on Hacker News just to kind of show people what we're doing and so, we got voted up to the front page that day and we got a spike of more than 2000 visitors over like the course of the next two days. We really got a lot of feedback from the forum thread on Hacker News, lots of people were responding whether they like our solution and they would want to see it doing, it also gave insights why users are not using all functionalities.” (LOC, 2012)

"The user feedback is very important, it makes users feel part of the product and also helps build a product people actually want rather than something that we think people want... We listen on our Twitter accounts, we have special email set up that we receive feedback on and we use that feedback to make adjustments to the product.” (HEL, 2014).

The purpose of having multiple iterations of the solution in the market is to test and validate the assumptions underlying the business model: "you take some very basic assumptions and you keep iterating and adding on, and we've done that” (MEC, 2012).

We conclude from the above that all four entrepreneurs valued the principles of the LSM and realized that adopting this method implies the formulation of a set of assumptions and hypotheses that need to be tested and validated (Ries 2011). Therefore, they have to experiment in the market in order to establish a workable business model (Blank 2013). While experimenting, entrepreneurs gather new information and gain new insights about how customers use their solution, how the sector operates and so on. This process of gradual learning and receiving feedback from the market enables entrepreneurs to revise their business model. As discussed by Ries (2011), a key objective of going through the iterative process is to adapt the offering and supporting business model as more market information is collected. Multiple iterations allow the entrepreneur to test the underlying assumptions of the offering quickly which enables refinement of the offering. Our empirical evidence indicates that all entrepreneurs in our 
study understand the importance of testing the product in the market, however as we will discuss later, they differ in the way they incorporate feedback in subsequent iterations of the offering and business model.

\section{Acting upon the market information: changing the business model}

Further analysis of the cases revealed that three start-ups pivoted by making a substantive change to the business model in response to feedback received from the market. During the follow-up interview in 2014, the founder of GRO told us that the initial idea changed from a combination of a dining card and group offers to a location finder for restaurants. In essence, the new solution would allow consumers to search for restaurants in a certain area based on their personal preferences (e.g. vegetarian, Italian etc.). Restaurants had to pay a monthly fee to GRO to be included in the solution. Essentially, the concept changed from a business-to-consumer approach to a business-to-business approach.

"we quickly realized after the first time we met [2012] that people are less concerned with offers, it's all about quality of places and location, offers are only secondary. We talked to a lot of people, we were constantly out talking to people... and then went back to the drawing board and we revised the plan. The new business model is kind of $\mathrm{B} 2 \mathrm{~B}$ predominantly: now we're charging restaurants whereas in the previous model we were charging customers."

Similarly, MEC made an important change to how they organize the pool of mechanics in their online matching platform between mechanics and customers. The founder of MEC told us the following regarding the changes made to the business model:

"We made some minor changes to the concept but we also had to make quite some drastic changes as well, especially for the mechanic. In terms of the supply side it's a completely new channel, something that we didn't use one year ago. Previously we used an inbound strategy where mechanics would send us in an application, we then had to call them up. This was a really good system but not a very cost-effective, very efficient system. Now we're moving towards a more outbound strategy making use of Facebook adds extensively for mechanic recruitment onto our platform. Scaling up the inbound 
strategy is almost impossible, it is extremely time-consuming. Now, we'll push the jobs to the mechanic like in an automated fashion."

The start-up LOC changed its offering significantly by departing from the initial idea to build a market place to buy and sell property. The revised offering of LOC targets the house sharing market via a solution to keep track of costs and share bills between housemates.

"we realized that the transactional space is really busy. So we started to look in the property market for some pain points that were more acute, where we could actually solve some problems building on our technology's functionality. We found that there doesn't really exist an operating platform for people to organize the information, services, and costs about their home... it exits in the commercial property market BUT not in the residential market" (Interview with the CEO, 2014).

One of the cases, HEL, did not make any significant changes to its business model. The product was launched in the market but never really got adopted by customers. The founder of the startup shared with us that he spent almost three years working on the product but it is "sort of like a dead end". During the interview in 2014, he said:

"I suppose we were very optimistic for two years. Turns out we were wrong, it's very uncertain right now; especially in terms of monetizing the product ... we don't really know what the future holds. We're not really changing the product anymore; the only thing that needs to be done is some minor maintenance of the code... We now prefer to stay small rather than to grow big."

The company adjusted its growth ambition and is now operating as a lifestyle business developing apps without "any of the aggressive marketing needed to realize rapid growth". In sum, we see that three of the four ventures made changes to their value proposition based on the feedback received from the market with the aim of improving product-market fit. The fourth company in contrast was not able to translate the feedback received from the market into an improved value proposition. The company mainly used market feedback to improve the code of product and thus focused primarily on making technical iterations.

\section{Adjusting resources in response to business model change}


Next, we analysed the resource-structuring behaviour of the three start-ups that changed their business model in more detail. Building on the resource orchestration framework by Sirmon et al. (2011), we focus on changes in human and social resources as they form the key resources in the start-up phase. The tables below give an overview of the list of resources of MEC, LOC, and GRO in 2012 and 2014.

\section{---INSERT TABLE 4 HERE---}

The above tables show that both MEC and LOC changed their human and social resources to a greater extent than GRO. MEC hired two additional employees to support the demand-side of the platform by performing specific tasks in customer service, content creation, and digital marketing. During the interview in 2014, the founder told us that they were looking to hire a senior sales manager. LOC also changed its resources in order to support the adjusted business model. A CEO joined who had specific knowledge about the real estate market while two of the original founders left the company to start a new business in a completely different sector (i.e. the betting industry). The CEO brought in an operations manager who has extensive experience in financial-oriented work in the real estate sector. He also shared with us during the interview in 2014 the following:

"I would like to hire a "community manager", a person who speaks the language of the house shares. In the new business model, relationship management with the house shares is very important. I experienced that I actually don't have the right voice. My voice is ok for the [previous solution], talking the property talk all the time"

In contrast, GRO did not make any significant changes to its resources in order to support its adjusted business model. When asking him what the implications were for the resources after changing the business model, he told us the following:

"The resources we need for the new concept are almost a mirror of those we needed for the old concept. The technology is very similar: both are based on geo mapping. Also the 
business development is basically the same activity: it is going out there speaking to restaurants and sign them onto our platform. The way we sell the solution is exactly the same, same material, we just changed the name, changed a few text. We had to change the company name etcetera to reflect this new value proposition, but we build upon the expertise that we developed within GRO to develop it. You'd be surprise that we don't have different company skills although we added a B2B partnership model. Everything is actually very similar, the only real difference is that before I was going working with a tshirt and now I have to work in a suit." (GRO, 2014)

Based on the further analysis of the three cases that adjusted their business model, MEC and LOC altered their resources to support the new business model whereas GRO did not make any change to its resource portfolio. The fact that GRO did not adjust its resources is surprising as an organization's resource portfolio and business model are tightly interrelated and fit between these two configuration processes is important for firm performance (Sirmon et al. 2011). Therefore, changes in the organization's business model should trigger resource-structuring behaviour as managers should acquire new resources necessary to implement the adjusted business model and/or divest existing resources that became obsolete because of the business model change. As emphasized by Sirmon et al. (2011), being able to adapt the resource portfolio experimentally in response to business model change is especially important in the start-up stage of organizations. This is also reflected in our empirical evidence, as we observed that the two ventures that altered their business model and associated resource configuration were also able to obtain external funding (MEC and LOC), while GRO did not.

\section{Being able to make effective business model change: the role of prior market knowledge}

Next, we analysed why MEC and LOC succeeded in pivoting their business model and modifying their resource base, while GRO did not. Further analysis of the cases points to the crucial role of prior market knowledge in the start-up to explain the differences in the start-ups' development paths. In MEC, the entrepreneur has a significant amount of knowledge about the car repair market at founding stemming from two important sources. On the one hand, the 
founder of MEC completed a one-year Master programme in Entrepreneurship at a leading business school in the UK. During this programme, he had to develop a business plan that allowed him to do an extensive analysis of the automotive repair market:

"I've done a lot of market research during my masters... a lot of primary market research, a lot of secondary market research. Doing a lot of interviews with people, talk to a lot of mechanics, doing focus groups and stuff like that."

Next to his own collected knowledge about the market, he could also rely extensively on the

experience and expertise of his older brother.

"My older brother is a car mechanic who owns a workshop. I don't have like deep connections at all in the industry [...] but the big connection has been my brother to be honest. I didn't speak to him so much the last two months but the early days or even not too long ago I was talking to him almost the other day and he was helping with stuff. He would just explain how the industry works, how it functions. He's worked in the industry since he's 18 he's 40 now so he's worked, been franchised, trained to master technician he opened his own workshop so he would've seen different type of car repair scenario's multiple times. He understands the industry very well...So to be able to lift up the phone to him and just ask what he thinks about this or that was extremely useful...Having this understanding of how mechanics currently do car repairs in different scenario's has been very useful.” (MEC, 2014).

The case of LOC also illustrates the importance of prior market knowledge particularly well. At start-up, the team consisted of a group of three recent graduates with a technical background that had little to no experience in the real estate market. However, this changed drastically when the new CEO joined the team in the second half of 2013:

"None of them had a huge amount of sort of, I guess, business experience and beyond technology, they certainly didn't have any real estate experience. So I met them with my other real estate technology company at the Open Data Institute and I got to know the guys. To make a very long story short: I ended up getting to advise them, then came on board full time as the CEO, brought in two new people, and reassessed the vision of the company... knowledge about the real estate market didn't exist one year ago and now I would say knowledge about the market is like significantly high" (LOC, 2014)

The CEO has almost ten years of experience in the real estate business before joining LOC. He was an early employee of a venture-capital backed real estate company where he was the head of 
Europe. One of the people who the CEO brought in also had been working for ten years in the real estate market. The CEO realised that what LOC had built, was nothing more than a cool widget. It was interesting, it got some people exited but there was kind of a glass ceiling, in terms of the amount of people that were coming to the website and the engagement it was creating and the amount of revenues.

"The initial idea was to actually build a market place to buy and sell property directly between people. After studying that piece of the market we found a few dozen sort of dead bodies, there's just loads of companies who tried and failed miserably. And the more and more we looked at the more we realised that clearly unless you have like 50 million or 100 million pounds behind you, there was no way you were gonna be able to be successful with this idea." (LOC, 2014).

Next, they basically spent pretty much the subsequent 12 months looking at various business models to build on LOC's functionality and to find some pains in the market that were more acute, where LOC could actually solve some problems that would get lots of people to come to the website. This resulted in a new business concept based on a platform to bring together all the information, services and costs about the home into a single platform so that people could actually make better decisions as consumers. The process LOC used to get to this new business concept also followed the principles of the lean start-up using iterative cycles of build-measurelearn feedback loop, similarly as before the CEO joined the start-up.

"So we then went back to the drawing board, did a huge amount of research and compared a first time renter versus a first time owner versus a later stage owner and looked at like which place should we actually enter the market. We kind of realised again, a lot of resource issues, and because of who the team actually was, it made sense to enter the market at the very beginning of the property journey. We also used like the sort of lean approach: bringing people in of the street, talking to them about their problems, creating maps like, and going through the process kind of properly. That's what enabled us to find our current path." (LOC, 2014).

The two ventures with prior market knowledge were better able to understand the market evolutions and to interpret new market information. Both MEC and LOC (after the new CEO 
joined) made important changes to their initial business concept and the supporting resource portfolio, which resulted in a better business model.

In GRO and HEL, the entrepreneurs had little to no experience in the market the start-up was operating in. The founder of GRO said in the interview in 2014 the following:

"We researched the market a lot last year. It was really unknown to us. We never used things like Groupon, I never used any deals things really. We just saw there was an opportunity... My co-founder used a couple of vouchers before, but still, we had to learn a lot about how vouchers are used, how the industry works, how the customers behave in that space, how businesses are working [...] We learned by speaking to people, searching online, everything, three-sixty approach I would say".

Also the founder of HEL acknowledged that he and his cofounder lacked market knowledge:

"We have to do our marketing and advertising ourselves, this is an area where we don't have a much experience. Our main skill is to make a good software product, how it should look like. It's product development."

GRO and HEL, which did not have prior market knowledge, were less able to interpret the information from users during the market research and iterative cycles compared to MEC and LOC (after the CEO joined). The adjustments that they made were more random and can be seen as lucky shots; there was no thorough understanding of the market feedback. Despite the fact that these ventures adopted the principles of lean start-up by actively seeking feedback on their offering, their lack of prior market knowledge withheld these ventures to take advantages of the feedback acquired from experimenting in the market. Consequently, both GRO and HEL were not able to adjust their business model and its supporting resource portfolio in such a way that they could be successful (i.e. attracting external capital to fuel their growth ambition).

Interestingly, the period before the new CEO joined LOC, i.e. when prior market was not present in the team, shows similarities to the trajectory of GRO and HEL. While LOC also followed the principles of the LSM in the period before the CEO joined the company (interview in 2012), they were unable to translate the outcomes of these experiments into an improved business model: 
"After we launched our initial prototype at the beginning of October, for a couple of months we were doing some kind of small iterations getting lots of feedback from various people. We're just iterating at the moment, the core concept and business model are in place. There may come a point where, if things don't work out, that we have to do some degree of a pivot, but that's not in our mind."

Using the LSM only resulted in some minor tweaking of the solution but did not lead to finding a better business model. For example, the entrepreneur could not answer questions about the revenue model of the business model:

"we don't have any revenues today. Maybe we can get revenues from real estate agencies via lead generation or maybe advertising on the properties? Marketing strategies is one of the big things we need to figure out... we have a list of several ideas but we'll see which of them are working..." (LOC, 2012)

The differences in the level of prior market knowledge across the four cases had an important influence on the learning that resulted from using the lean principles of rapid prototyping and market engagement during the study period. Our discussion above shows that using the lean start-up principles is more effective when prior market knowledge is available to the firm. Organizational learning is a process in which individuals acquire information via interactions with the environment, interpret this information, and update their beliefs about cause-effect relationships (Sinkula 1994). This learning process subsequently guides individual and organizational actions. The findings of our case study suggest that a crucial element in the learning from market feedback via the LSM is the extent to which entrepreneurs are able to interpret the acquired information. Only two cases reached an important milestone to realize their growth ambition: attracting external capital (MEC and LOC). These two start-ups were able to make productive changes to their business model and the supporting resource portfolio. In contrast, the two unsuccessful cases were not able to build a feasible business model (GRO and HEL). 


\section{DISCUSSION}

The purpose of this study was to gain a better understanding of how growth-oriented ventures can successfully apply the LSM, a popular venture experimentation method. Our findings show that merely using LSM by making product iterations is insufficient for new venture success and can even have detrimental effects leading to venture failure or downscaling of growth ambitions. Only when experimentation is combined with prior market knowledge, ventures are able to interpret new market information, leading to meaningful iterations and the development of strong problem-solution fits enabling them to attract external financing and move to the growth stage.

\section{Contributions to the literature}

Although LSM is a method rather than a theory, we have demonstrated that many of its principles show similarities with existing theoretical frameworks as illustrated in table 1 . As such, this paper serves to enhance the theoretical underpinning of the LSM by highlighting the commonalities with existing theories including venture experimentation, bricolage and effectuation besides the management theories acknowledged by Eric Ries (2011).

In addition, the empirical findings of our study enhance existing theory in two important ways. First, we contribute to the venture experimentation literature, popularized by the LSM, by explaining the boundaries of effective venture experimentation. Our study shows that prior market knowledge is needed for successfully applying the LSM. We demonstrate that scanning the market and collecting market insights only leads to meaningful iterations of the business model and supporting resource portfolio when there is sufficient prior market knowledge available in the firm to understand and interpret the acquired information. Prior knowledge captures the firm's absorptive capacity as it permits the assimilation and exploitation of new knowledge and allows the firm to better understand and evaluate new information (Cohen and 
Levinthal 1990). Therefore, the presence of prior market knowledge increases the learning pace, thereby increasing the effectiveness of experimentation that is feasible given the limited resource base. As such, our results provide more theoretical grounding for the popular concept of the LSM (Ries 2011) and reveal that prior market knowledge is an important boundary condition as it influences the extent to which applying the LSM will be more or less effective (see Busse et al, 2017 for a conceptual discussion of boundary conditions) $)^{2}$. Specifically, our findings suggest that applying the LSM will be more effective when the start-up has prior market knowledge. When entrepreneurs have no prior market knowledge, they are less able to make meaningful interpretation of the market information collected through experimentation with users/customers. This finding resonates with the organizational learning literature and market-based organizational learning in particular, which emphasizes that the interpretation of market information is key to organizational learning (Sinkula 1994). This literature views firms as information processing or interpretation systems that scan and collect data from their environments, interpret the data, and then learn by acting upon the interpretation (Daft and Weick 1984). Our study concludes that in an entrepreneurial context and by using popular venture experimentation methods such as the LSM, entrepreneurs quickly acquire a significant amount of market information. However, our case analysis shows that the interpretation of this market information distinguishes successful from unsuccessful ventures. Furthermore, revealing this boundary condition starts to answer the strong call of more research on "the shortcomings or the contexts in which popularized new tools and techniques such as the lean start-up can be more, or less, effective" (Kuratko and Morris 2015: 4).

\footnotetext{
${ }^{2}$ We thank an anonymous reviewer for pointing this out to us.
} 
Second, we contribute to the absorptive capacity and organisational learning literatures by showing how new ventures can create the capacity to interpret market feedback (Cohen and Levinthal 1990; Zahra and George 2002). We find that the ability to interpret acquired knowledge and information of a new venture can either be internal to the firm via prior market knowledge of team members or external to the firm via social resources. The case of LOC shows that it was only after the CEO joined that it was able to learn more effectively from use/customer feedback. The injection of prior market knowledge via the CEO gave LOC the ability to better interpret the information via the iterative cycles allowing the start-up to build a more promising business model. This finding underscores the importance of using longitudinal research design when analysing the influence of human capital variables such as prior market knowledge as team changes may have profound impact on the amount of prior market knowledge available to the firm.

Interestingly, our study further shows that absorptive capacity can also be external to the firm. Whereas existing literature considers absorptive capacity internal to the firm, the analysis of MEC suggests that the ability to interpret new knowledge may reside outside the firm. While the founder of MEC developed some initial understanding of the market during his master programme, it was especially the prior market knowledge of his brother $(>20$ years of experience in the car repair industry) that proved to be very useful. The founder of MEC accessed this prior market knowledge via very frequent interactions with his brother to discuss new information and feedback from users/customers. In essence, his brother helped the founder of MEC in interpreting external information and assessing what the implications are for the venture's business model. This shows that when absorptive capacity is external to the venture, it should be frequently accessible whenever needed and in close interaction with the founding team. This 
resonates with prior work showing that frequent and close interactions increase the breadth and depth of learning in relationships and contribute to knowledge acquisition (Lane and Lubatkin, 1998; Yli-Renko, Autio, and Sapienza, 2001).

In addition, the case of MEC also suggests that there may be a dynamic aspect to accessing absorptive capacity external to the firm. The founder told us that it was especially in the beginning period of MEC (2012) that he contacted his brother frequently but less today (interview, 2014). This may suggest that once the entrepreneur has acquired prior market knowledge and learned how to interpret market information through frequent and close interactions with the external source of absorptive capacity, he/she can make less use of this social resource as absorptive capacity is internalized. Entrepreneurs may therefore accelerate the development of internal absorptive capacity through close and frequent interactions with external sources of absorptive capacity. Future research is needed on external absorptive capacity and its potential temporary nature.

\section{Practical implications}

While the principles of the LSM appear very simple, we observe that adequately applying those principles is less straightforward than one might assume. The mere experimentation in the market with an MVP is not enough to discover product-market fit and develop a viable business model. Our empirical evidence shows that not every entrepreneur was capable of processing the extensive market information that this method brings along. As a result, their limited resources were not spent efficiently as the next iteration of the product did not capture the market insights but were rather an unguided exploratory attempt to search for the desired product-market fit. This implies that LSM is limited to a certain time window - one cannot stay lean forever because of the costs associated with the MVP-approach advocated by authors such as Blank and Ries. As 
such, it is not a one-fit-all solution, given the crucial role of the level of prior market knowledge of the entrepreneur in applying the LSM effectively.

Our study has also practical implications for student entrepreneurs or entrepreneurs that recently graduated and have little to no working experience. These entrepreneurs often lack prior market knowledge and have a very limited network, which means that they have difficulties to find investors, making the lean start-up approach very inviting. However, our study shows the importance of acquiring market knowledge or at least developing structures that allow entrepreneurs to tap into external sources of prior market knowledge whenever they need it in a fast and efficient way.

This paper also has practical implications for current structures that advice and monitor new ventures such as accelerator programs, board of directors or independent mentors and experts. The typical monthly board of director meetings or irregular meetings with independent mentors or experts are not sufficient as young entrepreneurs can only crosscheck every month or irregularly with market experts while decisions need to be made much faster. This could partially explain why accelerators such as Y-combinator are successful as they have very intensive mentoring programs involving people with relevant market knowledge.

Finally, the results have also broader practical implications as entrepreneurs easily get into situations of high uncertainty where individual agency must be brought to bear in uncovering market knowledge critical to applying LSM effectively ${ }^{3}$. In turbulent, difficult and even counter-intuitive contexts, LSM can become even more impactful, just like the boundary conditions identified in our study. For example, Alvi \& Carsrud (2017) study entrepreneurs in international, emerging markets and set out the construct of strategic entrepreneurial agency

\footnotetext{
${ }^{3}$ We thank an anonymous reviewer for pointing this out to us
} 
which is the individual agency of entrepreneurs, who in responding to the challenging institutional contexts of emerging markets improvise impromptu strategies to exploit unexpected opportunities where others see none. They are involved in creating market knowledge in entrepreneurial ways when they have little to no pre-existing knowledge. Our study provides insights into how entrepreneurs can better interpret and understand new market information without having any prior market experiences.

\section{LIMITATIONS AND FUTURE RESEARCH}

As all empirical studies, our study has several limitations that provide opportunities for further research. First, we selected four ventures operating in the ICT sector based in London. Using such a homogenous set of cases has the advantage of reducing the potential influence of the external environment. However, future research needs to examine growth-oriented start-ups in different contexts such as different industries and/or countries in order to establish the generalizability of our findings and further improve the robustness of the insights provided by our study.

Second, we focused on young, growth-oriented entrepreneurs that are by nature more willing to raise external finance and are not afraid of losing some control over their ventures (Manigart and Struyf 1997; Sapienza, Korsgaard, and Forbes 2003). Future research might usefully consider including teams that consists of members with prior working and/or entrepreneurial experience into their analysis. The amount of prior experience (technology/market/entrepreneurial) has an important imprinting effect on new venture development (Beckman and Burton 2008) and the search behaviour of entrepreneurs (e.g. Gruber, MacMillan and Thompson 2013); which influence how new ventures apply the LSM. 
TABLES

Table 1: LSM: underlying theoretical frameworks and relevant principles

\begin{tabular}{|c|c|c|c|c|c|c|c|}
\hline & $\begin{array}{l}\text { Discovery } \\
\text { driven } \\
\text { planning }\end{array}$ & \begin{tabular}{|l|} 
Design \\
thinking
\end{tabular} & $\begin{array}{l}\text { Lean } \\
\text { manufacturing }\end{array}$ & \begin{tabular}{|l} 
Agile \\
development
\end{tabular} & $\begin{array}{l}\text { Venture } \\
\text { experimentation }\end{array}$ & Effectuation & Bricolage \\
\hline Key authors & $\begin{array}{l}\text { McGrath and } \\
\text { MacMillan } \\
(1995 ; 2009)\end{array}$ & $\begin{array}{l}\text { Archer } \\
(1965)\end{array}$ & Krafcik (1988) & $\begin{array}{l}\text { Highsmith and } \\
\text { Cockburn } \\
(2001) \\
\text { Iansiti and } \\
\text { MacCormack } \\
\text { (1997) }\end{array}$ & $\begin{array}{l}\text { Nicholls-Nixon, } \\
\text { Cooper, and } \\
\text { Woo }(2000)\end{array}$ & $\begin{array}{l}\text { Sarasvathy } \\
(2001)\end{array}$ & \begin{tabular}{|l|} 
Baker and \\
Nelson $(2005)$
\end{tabular} \\
\hline \begin{tabular}{|l|} 
Scope \\
(primary area \\
of application)
\end{tabular} & \begin{tabular}{|l|} 
New ventures \\
within big \\
corporations
\end{tabular} & \begin{tabular}{|l} 
New \\
products/ \\
services
\end{tabular} & $\begin{array}{l}\text { Operations } \\
\text { management }\end{array}$ & $\begin{array}{l}\text { Software } \\
\text { development }\end{array}$ & New ventures & New ventures & New ventures \\
\hline \begin{tabular}{|l|} 
Environment \\
\end{tabular} & $\begin{array}{l}\text { Uncertain and } \\
\text { unpredictable } \\
\text { environment }\end{array}$ & \begin{tabular}{|l|} 
Rapidly \\
changing \\
environment
\end{tabular} & $\begin{array}{l}\text { Industries } \\
\text { competing on } \\
\text { productivity } \\
\text { and efficiency }\end{array}$ & \begin{tabular}{|l|} 
Rapidly \\
changing \\
environment
\end{tabular} & $\begin{array}{l}\text { Uncertain and } \\
\text { unpredictable } \\
\text { environment }\end{array}$ & $\begin{array}{l}\text { Knightian } \\
\text { uncertainty }\end{array}$ & $\begin{array}{l}\text { Tight resource } \\
\text { constraints }\end{array}$ \\
\hline \begin{tabular}{|l|} 
Main \\
principles
\end{tabular} & $\begin{array}{l}\text { Reduce } \\
\text { uncertainty by } \\
\text { experimentation }\end{array}$ & $\begin{array}{l}\text { Interaction } \\
\text { with users } \\
\text { /customers }\end{array}$ & $\begin{array}{l}\text { Waste } \\
\text { minimization } \\
\text { without } \\
\text { sacrificing } \\
\text { productivity }\end{array}$ & \begin{tabular}{|l} 
Pivot (rapid \\
and flexible \\
response to \\
change) \\
Customer \\
involvement
\end{tabular} & \begin{tabular}{|l|} 
Reduce \\
uncertainty by \\
experimentation
\end{tabular} & $\begin{array}{l}\text { Birds in hand } \\
\text { (focus on } \\
\text { means) } \\
\text { Lemonade } \\
\text { (leverage } \\
\text { contingencies) } \\
\text { Affordable } \\
\text { loss (focus on } \\
\text { downside) } \\
\text { Crazy quilt } \\
\text { (co-creation } \\
\text { partnerships) } \\
\end{array}$ & $\begin{array}{l}\text { Making do } \\
\text { Recombination } \\
\text { of resources } \\
\text { (for new } \\
\text { purposes) }\end{array}$ \\
\hline $\begin{array}{l}\text { Commonalities } \\
\text { with LSM }\end{array}$ & Experimentation & $\begin{array}{l}\text { Customer } \\
\text { focus }\end{array}$ & $\begin{array}{l}\text { Waste } \\
\text { minimization }\end{array}$ & \begin{tabular}{|l} 
Iterative \\
development
\end{tabular} & Experimentation & $\begin{array}{l}\text { Decision } \\
\text { making under } \\
\text { uncertainty } \\
\text { Stakeholder } \\
\text { interaction }\end{array}$ & $\begin{array}{l}\text { Resource } \\
\text { efficiency } \\
\text { Iterative } \\
\text { development } \\
\text { Stakeholder } \\
\text { interaction }\end{array}$ \\
\hline
\end{tabular}

Table 2: Overview of data sources

\begin{tabular}{|l|c|c|c|c|}
\hline & MEC & LOC & HEL & GRO \\
\hline \# Interviews & 4 & 4 & 4 & 4 \\
\hline Respondents & Lead founder & $\begin{array}{c}\text { Lead founder } \\
\text { and his co- } \\
\text { founders }\end{array}$ & Lead founder & Lead founder \\
\hline Length interviews (min.) & 168 & 224 & 90 & 158 \\
\hline Interview transcripts (Pages) & 40 & 56 & 25 & 47 \\
\hline $\begin{array}{l}\text { Press releases and coverage } \\
\text { (pages) }\end{array}$ & 35 & 33 & 39 & 18 \\
\hline LinkedIn profiles (pages) & 5 & 9 & 3 & 5 \\
\hline YouTube conference and & 5 presentations & 2 presentations & No & 5 presentations \\
\hline
\end{tabular}


company presentations and

interviews (\# and min.)

$14 \min$

$2 \mathrm{~min}$

presentations found

$5 \mathrm{~min}$

Table 3: Case Characteristics

\begin{tabular}{|c|c|c|c|c|}
\hline & MEC & GRO & LOC & HEL \\
\hline $\begin{array}{l}\text { Description of } \\
\text { activity }\end{array}$ & $\begin{array}{l}\text { An online platform } \\
\text { where people that } \\
\text { have to repair their } \\
\text { car can } \\
\text { get instant, industry } \\
\text { standard approved } \\
\text { quotes and book a } \\
\text { mechanic online }\end{array}$ & $\begin{array}{l}\text { An online } \\
\text { platform where } \\
\text { people can sign in } \\
\text { on deals in group } \\
\text { and get discounts } \\
\text { or extra options, } \\
\text { saving money in a } \\
\text { discrete fashion. }\end{array}$ & $\begin{array}{l}\text { Built around an } \\
\text { area finding } \\
\text { technology that } \\
\text { leveraged open } \\
\text { data sets on } \\
\text { transportation } \\
\text { time, local } \\
\text { amenities, telling } \\
\text { customers to } \\
\text { figure out where } \\
\text { they wanted to } \\
\text { live }\end{array}$ & $\begin{array}{c}\text { Develop and } \\
\text { commercialize } \\
\text { consumer apps for } \\
\text { mobile devices. } \\
\text { Their first and main } \\
\text { product was a } \\
\text { simple task manager } \\
\text { app with a clutter- } \\
\text { free interface which } \\
\text { makes it easier to } \\
\text { stay organised. }\end{array}$ \\
\hline Founding date & 2012 & 2011 & 2012 & 2011 \\
\hline $\begin{array}{l}\text { Founding team } \\
\text { size }\end{array}$ & 2 & 2 & 3 & 2 \\
\hline $\begin{array}{l}\text { Founding team } \\
\text { experience }\end{array}$ & $\begin{array}{c}\text { Lead founder: } \\
\text { Collected market } \\
\text { knowledge through } \\
\text { extensive market } \\
\text { research prior to } \\
\text { start-up, some } \\
\text { entrepreneurial } \\
\text { experience in } \\
\text { closely related } \\
\text { markets } \\
\text { Co-founder: No in- } \\
\text { depth market } \\
\text { experience, } \\
\text { experience in front- } \\
\text { and back-end } \\
\text { development of } \\
\text { websites and apps. }\end{array}$ & $\begin{array}{l}\text { Lead founder: No } \\
\text { in-depth market } \\
\text { experience, } \\
\text { experience in } \\
\text { management } \\
\text { consulting } \\
\text { Co-founder: No } \\
\text { in-depth market } \\
\text { experience, } \\
\text { experience as } \\
\text { music artist } \\
\text { manager }\end{array}$ & $\begin{array}{l}\text { Founder 1: No in- } \\
\text { depth market } \\
\text { experience, } \\
\text { experience as } \\
\text { technical } \\
\text { consultant } \\
\text { Founder 2: No in- } \\
\text { depth market } \\
\text { experience, } \\
\text { experience as } \\
\text { commercial } \\
\text { strategy specialist } \\
\text { Founder 3: No in- } \\
\text { depth market } \\
\text { experience, } \\
\text { experience as } \\
\text { software engineer }\end{array}$ & $\begin{array}{l}\text { Lead founder: No } \\
\text { in-depth market } \\
\text { experience, some } \\
\text { entrepreneurial } \\
\text { experience as } \\
\text { student, education= } \\
\text { computer science } \\
\text { Co-founder: No in- } \\
\text { depth market } \\
\text { experience, some } \\
\text { entrepreneurial } \\
\text { experience as } \\
\text { student, education= } \\
\text { computer science }\end{array}$ \\
\hline $\begin{array}{l}\text { Starting capital (in } \\
£ \text { ) }\end{array}$ & 5.000 & 1.000 & 5.000 & 1.000 \\
\hline $\begin{array}{l}\text { External funding } \\
\text { (in } £ \text { ) }\end{array}$ & 320.000 & 0 & 800.000 & 0 \\
\hline $\begin{array}{l}\text { Date of raising } \\
\text { external funding }\end{array}$ & 24 April 2015 & / & 28 October 2015 & 1 \\
\hline Company status/ & Active/ growth- & Inactive & Active/ growth- & Active/ lifestyle \\
\hline
\end{tabular}




\begin{tabular}{|l|l|l|l|l|}
\hline $\begin{array}{l}\text { Growth } \\
\text { orientation }\end{array}$ & oriented & oriented & $\begin{array}{c}\text { business (no longer } \\
\text { growth-oriented) }\end{array}$ \\
\hline
\end{tabular}

Table 4: Overview of changes in human and social capital

\begin{tabular}{|l|l|l|}
\hline & \multicolumn{2}{|c|}{ MEC } \\
\hline & \multicolumn{1}{|c|}{2012} & \multicolumn{1}{c|}{2014} \\
\hline Human & Founder1 & Founder1 \\
Founder2 & $\begin{array}{l}\text { Founder2 } \\
\text { 1 employee responsible for customer service } \\
1 \text { employee responsible for content creation and digital marketing }\end{array}$ \\
\hline Social & Brother & \multicolumn{1}{|c|}{} \\
\hline
\end{tabular}

\begin{tabular}{|l|l|l|}
\hline & \multicolumn{2}{|c|}{ LOC } \\
\hline & \multicolumn{1}{|c|}{2012} & \\
\hline Human & Founder1 & Founder1 \\
& Founder2 & CEO \\
& Founder3 & 1 operations manager \\
& & 1 employee for digital marketing \\
& & 1 software engineer \\
\hline Social & 1 freelancer for development and design & 2 freelancers for development and design \\
\hline
\end{tabular}

\begin{tabular}{|l|l|l|}
\hline & \multicolumn{2}{|c|}{ GRO } \\
\hline & \multicolumn{1}{|c|}{2012} & \\
\hline Human & Founder1 & Founder1 \\
& Founder2 & Founder 2 \\
& CTO & CTO \\
\hline Social & $\begin{array}{l}\text { Brother } \\
\text { 2 freelancers for development and design }\end{array}$ & 1 freelancers for development and design \\
\hline
\end{tabular}

\section{REFERENCES}

Ahsan, M., Zheng, C., DeNoble, A., and M. Musteen (2018). "From Student to Entrepreneur: How Mentorships and Affect Influence Student Venture Launch," Journal of Small Business Management 56(1), 76-102.

Alvi, F. H., \& Carsrud, A. L. (2017). "Strategic Entrepreneurial Agency in Emerging Markets." The Journal of Entrepreneurship, 26(1), 77-101.

Archer, Leonard B (1965). Systematic Method for Designers. Council of Industrial Design, H.M.S.O.

Ariño, A., and P.S. Ring (2010). "The role of fairness in alliance formation," Strategic Management Journal, 31(10), 1054-1087.

Bhawe, N., Rawhouser, H., and J.M. Pollack (2016). "Horse and cart: The role of resource acquisition order in new ventures," Journal of Business Venturing Insights 6, 7-13. 
Beckman, C. M., and M.D. Burton (2008). "Founding the future: Path dependence in the evolution of top management teams from founding to IPO," Organization Science 19(1), 3-24.

Blank, S. (2013). "Why the lean start-up changes everything," Harvard Business Review 91(5), 63-72.

Bojovic, N., Genet, C., and V. Sabatier (2018). "Learning, signaling, and convincing: The role of experimentation in the business modeling process," Long Range Planning 51(1), 141-157

Bosma, N., and E. Stam (2012). Local policies for high-employment growth enterprises," in Report prepared for the OECD/DBA international workshop on high-growth firms: local policies and local determinants, Copenhagen.

Breuer, H. (2013)." Lean venturing: learning to create new business through exploration, elaboration, evaluation, experimentation, and evolution," International Journal of Innovation Management 17(3), 1340013.

Camuffo, A., Cordova, A., and A. Gambardella (2017). "A scientific approach to entrepreneurial experimentation evidence from a randomized control trial," Working paper. April 2017.

Cohen, S., and Y.V. Hochberg (2014). "Accelerating Startups: The Seed Accelerator Phenomenon". SSRN Electronic Journal.

Cohen, W. M., and D.A. Levinthal (1990). "Absorptive capacity: A new perspective on learning and innovation," Administrative Science Quarterly 35(1), 128-152.

Daft, R. L., and K.E. Weick (1984). "Toward a model of organizations as interpretation systems," Academy of Management Review 9(2), 284-295.

Danneels, E. (2003). "Tight-loose coupling with customers: the enactment of customer orientation," Strategic Management Journal 24(6), 559-576.

Danneels, E. (2007). “The process of technological competence leveraging," Strategic Management Journal 28(5), 511-533.

Danneels, E. (2011). "Trying to become a different type of company: dynamic capability at Smith Corona," Strategic Management Journal 32(1), 1-31.

Eisenhardt, K. M. (1989). "Building theories from case study research," Academy of Management Review 14(4), 532-550.

Eisenhardt, K. M., and M.E. Graebner (2007). "Theory building from cases: Opportunities and challenges," Academy of Management Journal 50(1): 25-32.

Eisenmann, T. R., Ries, E., and S. Dillard (2012). "Hypothesis-Driven Entrepreneurship: The Lean Startup (SSRN Scholarly Paper No. ID 2037237)," Rochester, NY: Social Science Research Network. Retrieved from https://papers.ssrn.com/abstract=2037237.

Fisher, Greg. 2012. "Effectuation, Causation, and Bricolage: A Behavioral Comparison of Emerging Theories in Entrepreneurship Research.” Entrepreneurship Theory and Practice 36 (5): 1019-51.

Fitza, M., Matusik, S. F., and E. Mosakowski (2009). "Do VCs Matter? The Importance of Owners on Performance Variance in Start-up Firms," Strategic Management Journal 30(4), 387-404. 
Gans, J. S., Stern, S. and J. Wu (2016). "Foundations of Entrepreneurial Strategy," Working Paper Available at SSRN: https://ssrn.com/abstract=2844843.

Gehman, J., Glaser, V. L., Eisenhardt, K. M., Gioia, D., Langley, A., and K.G. Corley (2018). "Finding theory-method fit: A comparison of three qualitative approaches to theory building," Journal of Management Inquiry 27(3) 1-18.

Gbadegeshin, S. A., and L. Heinonen (2016). "Application of the Lean Start-up technique in commercialisation of business ideas and innovations," International Journal Of Business Management and Research 43(1), 1270-1285.

Gruber, M., MacMillan, I. C., and J.D. Thompson (2013). "Escaping the prior knowledge corridor: What shapes the number and variety of market opportunities identified before market entry of technology startups?," Organization Science 24(1), 280-300.

Harms, R. (2015). "Self-regulated learning, team learning and project performance in entrepreneurship education: Learning in a lean start-up environment," Technological Forecasting and Social Change 100, 21-28.

Harms, R., Marinakis, Y., and S.T. Walsh (2015). "Lean startup for materials ventures and other sciencebased ventures: under what conditions is it useful?," Translational Materials Research 2(3), 35001.

Hellmann, T., and M. Puri (2002). "Venture Capital and the Professionalization of Start-up Firms: Empirical Evidence," Journal of Finance 57(1), 169-197.

Highsmith, J., and A. Cockburn (2001). "Agile software development: the business of innovation," Computer 34(9), 120-127.

Hochberg, Y. V., Ljungqvist, A., and Y. Lu (2007). "Whom You Know Matters: Venture Capital Networks and Investment Performance," Journal of Finance 62(1), 251-301.

Hsu, D. H. (2007). "Experienced entrepreneurial founders, organizational capital, and venture capital funding," Research Policy 36(5), 722-741.

Iansiti, M., and A. MacCormack (1997). "Developing products on Internet time," Harvard Business Review 75(5), 108-117.

Kerr, W. R., Nanda, R., and M. Rhodes-Kropf (2014). "Entrepreneurship as experimentation," Journal of Economic Perspectives 28(3), 25-48.

Kohavi, R., Deng, A., Frasca, B., Walker, T., Xu, Y., and N. Pohlmann (2013). “Online Controlled Experiments at Large Scale," Conference Paper KDD. Chicago, IL.

Krafcik, J. F. (1988). “Triumph Of The Lean Production System,” Sloan Management Review 30(1), 41.

Kuratko, D. F., and M.H. Morris (2018). "Examining the Future Trajectory of Entrepreneurship," Journal of Small Business Management 56(1), 11-23

Ladd, T., and L. Kendall (2017). "Entrepreneurial Cognition in the Lean Startup Method," Academy of Management Proceedings 2017,10753. 
Lane P.J., and M. Lubatkin (1998). "Relative absorptive capacity and interorganizational learning," StrategicManagement Journal 19(8), 461-477.

Lewis, R. A., and J.M. Rao (2015). "The unfavorable economics of measuring the returns to advertising," Quarterly Journal of Economics 130(4), 1941-1973.

Lutz, L. M., Fischer, L.-B., Newig, J., and D.J.Lang (2017). "Driving factors for the regional implementation of renewable energy - A multiple case study on the German energy transition," Energy Policy 105, 136-147.

MacCormack, A., Verganti, R., and M. Iansiti (2001). "Developing Products on "Internet Time": The Anatomy of a Flexible Development Process," Management Science 47(1), 133-150.

Ma, S., and D. Seidl (2016). "New CEOs and their collaborators: Divergence and convergence between the strategic leadership constellation and the top management team," Strategic Management Journal 39(3), 606-638.

Martin, R. (2009). The Design of Business: Why Design Thinking is the Next Competitive Advantage. Harvard Business School Press, Boston MA.

Maurya, A. (2012a). Running Lean: Iterate from Plan A to a Plan That Works. O'Reilly Media, Inc.

Maurya, A. (2012b, February 27). Why Lean Canvas vs Business Model Canvas? Retrieved May 15, 2018, from https://blog.leanstack.com/why-lean-canvas-vs-business-model-canvas-af62c0f250f0

Manigart, S., and C. Struyf (1997). "Financing high technology startups in Belgium: An explorative study," Small Business Economics 9(2), 125-135.

McGrath, R. G. and I.C. MacMillan (1995). "Discovery Driven Planning,” Harvard Business Review 73 (4), 44-54.

McGrath, R. G. and I.C. MacMillan (2009). Discovery Driven Growth: A Breakthrough Process to Reduce Risk and Seize Opportunity. Harvard Business Publishing, Boston MA.

Miles, M. B., and A.M. Huberman (1984). Qualitative data analysis. Beverly Hills, CA: Sage.

Baker, Ted, and Reed E. Nelson (2005). 'Creating Something from Nothing: Resource Construction through Entrepreneurial Bricolage,’ Administrative Science Quarterly, 50 (3), 329-66.

Nicholls-Nixon, C. L., Cooper, A. C., and C.Y. Woo (2000). "Strategic experimentation: Understanding change and performance in new ventures," Journal of Business Venturing 15(5), 493-521.

Nirwan, M. D., and W. Dhewanto (2015). "Barriers in Implementing the Lean Startup Methodology in Indonesia - Case Study of B2B Startup,” Procedia - Social and Behavioral Sciences 169, 23-30.

Osterwalder, A., and Y. Pigneur (2013). Business Model Generation: A Handbook for Visionaries, Game Changers, and Challengers. John Wiley and Sons.

Patton, M. Q. (2002). Qualitative research and evaluation methods (3rd ed.). Thousand Oaks, CA: Sage.

Pratt, M. G. (2009). "From the editors: For the lack of a boilerplate: Tips on writing up (and reviewing) qualitative research," Academy of Management Journal 52(5): 856-862. 
Rasmussen, E. S., and S. Tanev (2016). “Lean start-up: Making the start-up more successful,” In Start-Up Creation (pp. 39-56). Woodhead Publishing.

Ries, E. (2011). The lean start-up: How today's entrepreneurs use continuous innovation to create radically successful businesses. New York: Crown Business.

Root, A. (n.d.). VCs Want to See Product-Market Fit: Here's How to Prove It. Retrieved October 13, 2017, from https://www.entrepreneur.com/article/284890

Sapienza, H. J., Korsgaard, M. A., and D. Forbes (2003). The self-determination motive and entrepreneurs' choice of financing," Cognitive Approaches to Entrepreneurship Research 6:105-138.

Sarasvathy, Saras D. (2001). 'Causation and Effectuation: Toward a Theoretical Shift from Economic Inevitability to Entrepreneurial Contingency,' Academy of Management Review, 26 (2), 243-63.

Shepherd, D. A., K.M. and Sutcliffe (2011). "Inductive top-down theorizing: A source of new theories of organization," Academy of Management Review 36(2), 361-380.

Sinkula, J. M. (1994). "Market information processing and organizational learning". Journal of Marketing $58(1), 35-45$

Sirmon, D. G., Hitt, M. A., Ireland, R. D., and B.A. Gilbert (2011). "Resource orchestration to create competitive advantage breadth, depth, and life cycle effects," Journal of Management 37(5), 1390-1412.

Sonenshein, S. (2014). How organizations foster the creative use of resources. Academy of Management Journal 57(3), 814-848.

Smith, R. P., and S.D. Eppinger (1997). "Identifying controlling features of engineering design iteration," Management Science 43(3), 276-293.

Still, K. (2017). Accelerating Research Innovation by Adopting the Lean Startup Paradigm. Technology Innovation Management Review 7(5), 32-43.

Tanev, S., Rasmussen, E. S., Zijdemans, E., Lemminger, R., and L.L. Svendsen (2015). "Lean and Global Technology Start-Ups: Linking the Two Research Streams," International Journal of Innovation Management 19(03), 1-41.

Thomke, S. H. (1998). Managing experimentation in the design of new products. Management Science 44(6), 743-762.

Thomke, S. H. (2001). "Enlightened experimentation. The new imperative for innovation," Harvard Business Review 79(2), 66-75.

Thomke, S., and J. Manzi (2014). "The Discipline of Business Experimentation," Harvard Business Review 92(12), 70-79.

Vaughan D. (1992). Theory elaboration: the heuristics of case analysis. In What is a Case?, Ragin CC, Becker HS (eds). Cambridge University Press: New York; 173-202.

Vogel, P. (2016). “From venture idea to venture opportunity," Entrepreneurship Theory and Practice 
Yli-Renko H, Autio E, H.J. Sapienza (2001). "Social capital, knowledge acquisition, and knowledge exploitation in young, technology-based firms," Strategic Management Journal 22(6-7), 587-613.

Zahra, S. A., and G. George (2002). "Absorptive capacity: A review, reconceptualization, and extension," Academy of Management Review 27(2), 185-203. 